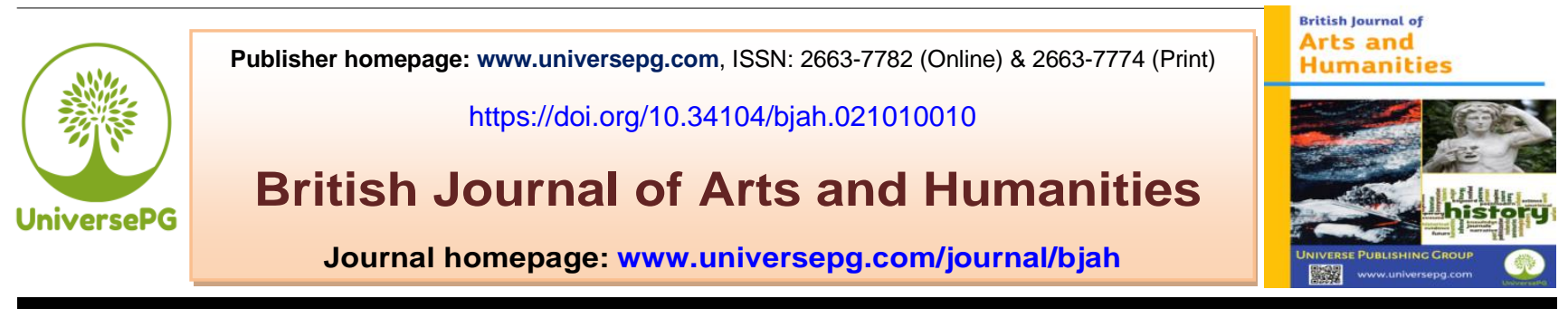

\title{
Impact of Foucauldian Discourse on Feminism and Postcolonial Studies
}

\author{
Yasif Ahmad Faysal ${ }^{1 *}$ and Md. Mijanur Rahman ${ }^{2}$ \\ ${ }^{1 \& 2}$ Department of English, Faculty of Arts and Humanities, University of Barishal, Barishal, Bangladesh. \\ *Correspondence: yasiffaysal@gmail.com (Yasif Ahmad Faysal, Assistant Professor, Department of English, University \\ of Barishal, Barishal, Bangladesh).
}

\begin{abstract}
Foucault's concept of power and its working in a complex process for the formation of identity and the mobilization of resistance has been of paramount interest over the years to individuals and groups located in unfavorable positions in power-relations. That knowledge and power work together in an exclusionary formation signified in the concept of discourse has inspired feminists and theorists of colonial and postcolonial studies to rework discourse theories to map out new identities and programs of resistance. Although Foucault's ideas are appropriated by critical schools for various reasons, such appropriation still requires a measure of clarification, since there is no unified position among the schools themselves. In this paper, We therefore attempt to show how themes of exclusion, identity and resistance-very seminal to Foucault's critical oeuvre, are received and modified by feminist thinkers and theorists of colonial and postcolonial studies.
\end{abstract}

Keywords: Discourse, Exclusion, Resistance, Narrative, Homogenization, Feminism, and Reification.

\section{INTRODUCTION:}

Michael Foucault's impact in the development of the critical schools of the twentieth century has been remarkable. As the overarching influence of Marxism and Freudism came to be revised, if not challenged, by the poststructuralist ideas and by those inspired by the phenomenon of decolonization around the globe, Foucault's intellectually engaging contribution about notions of identity, history and resistance came to work as organizing principle for critical consciousness that wanted to map out a radical existence in a pluralistic and politically altered world.

His critical engagement with the concept of the peripheral as inscribing a powerful trajectory to the mainstream has been compelling to schools of thinking disinclined to embrace the monolithic interpretation of the past. That is why, for feminist theorists and those of the colonial and post-colonial studies, Foucault's insight as to how a highly structured process of exclusion is involved in the production of knowledge, how such knowledge produces conflicting and multiple identities/ subjectivities and how power is reconfigured to be challenged and resisted from multiple points of transmission, exchange and negotiation, are considered very important (Akter et al., 2019).

While these schools are indebted to Foucault's intellectual contribution, it remains to be seen to what extent and to what degree precisely, Foucault's ideas, in their rich fecundity and profusion, actually shaped and formed the unique nature of the critical schools mentioned above.

In this article, we attempt to investigate different strands of Foucault's ideas and their constitutive role for the above-mentioned areas of critical thinking. 


\section{Foucault's Concept of Identity, Exclusion and Resistance}

"What I have said is not what I think but often what I wonder whether it couldn't be thought" (Foucault, 1979d).

The singular spirit of Foucault's study begins with the stupendous task of dismantling the belief that knowledge is an expression of men's ideas (Macdonnel, 1986). This counter-intuitive understanding of knowledge as a serious, rigorous process of exclusion draws attention to the heart of reality where certain formations are labelled as truth and others (that are excluded) false. Truth, therefore is a product of circumstances:

"Truth is of the world; it is produced there by virtue of multiple constraints ... Each society has its regime of truth, its general politics of truth ..." (Foucault, 1979e).

Foucault envisions truth not as a quality existing in a vacuum but as discourse useful for its instrumentality and for its imbrications with power (Mills, 1997). In The Archeology of Knowledge, (1972), Foucault explains that the process of exclusion inherent in the formation of discourse is quite complex and depends on a number of levels. According to Foucault, discourse is a structure or grouping of utterances around a theme strictly regulated, rule-governed, internally hierarchized (Mills, 51). He identifies three specific aspects of the regulating principles of a discursive-formation: delimitation of a field of objects, the definition of a legitimate perspective for the agent of knowledge, and the fixing of norms for the elaboration of concepts or theories (Foucault, 1977a).

While the first aspect implies a narrowing down of perspective and production of fixed statements at the exclusion of certain phenomena, the second one expresses the need for a legitimizing authority to carry out the task of exclusion. The third aspect maps out the chart in which the statements produced encode the possibility of further use strictly in accordance with the designated norms and parameters of the discursive structure (Mills, 1997).

The most recognized and institutionalized form of exclusion is embodied in the construction of 'episteme' and 'archive'-an ordered aggregation of discursive-structures with methodological support- systems ensuring that a certain kind of statements are kept in circulation (Mills,1997). Foucault who is not an avowed proponent of the continuist idea of history (ibid) argues as in The History of Sexuality $($ Vol 1,2,3) that western epistemes have always made it a point to consider death and sexuality as two taboo-topics in any form of discourse, while the 'will to truth' (Foucault, 1981) has been the spirit behind the obsessive and legalistic compartmentalization of knowledge (Davis,1983). Discourse employs the service of commentary and academic discipline, along with rarefaction, as internal regulators providing reinforcement and methodologies for one to speak 'in the true' (Foucault, 1981) and to ritualize the process of domination and submission (Mills, 1997). Foucault has no doubt that we are mostly unaware of the 'prodigious machinery designed to exclude (Foucault, 1981).

Exclusion is directly linked to the formation of counter-subjectivity. Outside the bounded surface of discourse is the region of exclusion. The stricter a discourse operates in its censoring function, the greater is the possibility for the formation of 'reverse discourse' (Bristow 179) and 'the intensification of the interventions of power to a multiplication of discourse' (Foucault, 1978). Institutional intervention is always counterproductive: it heightens awareness of exclusion and brings about the entrenchment of radical identities. Foucault's point is that corresponding to the degree of coerciveness, identity takes up the shapes of being asymmetric and polar (Frow, 1986). And Marxist linguist Michel Pecheux agrees with Foucault: it is only by disidentification; one can construct oneself as subject within a discourse and chart out a potentially liberating space for existence (Mills, 1957).

Foucault's vision of liberating space (if he has any) is allied to a mode of power where resistance plays a central part. By debunking the 'repressive hypothesis' (Mills, 1997) in the ideological form of power, he moved to the relational character of power of the nature of 'tactical polyvalence' (Bristow, 2001). The term refers to the strategic condition of power, in which it can be appropriated from multiple locations. This is a significant transition in Foucault's thinking-if the polyvalence of power is connected to his equally important views that there is no retrospective unity of history and that man is not after all the elementary nucleus (Hamilton), we 
move to a watershed stage of Foucault's powerconcept where power and its hierarchical embodiments are articulated as signifying reconfigured dominance and subordination (Bristow 2001). That resistance in the form of counterdiscourse can originate from any direction under any given configuration Foucault has no doubt of:

"Power comes from below: that is there is no binary and all-encompassing opposition between rulers and ruled at the root of power relations ..." (Foucault, 1978).

From a technical point of view, resistance is coeval with power in the same way as the exclusion is with subjectivity (Foucault, 1978). Of course in the broader scopes of theoretical applications in the areas such as feminism and post-colonialism, Foucault's ideas are open to debate: that is a testament to the continuing relevance of his ideas and the degree of their adaptability in a fast changing world.

\section{Foucault and Feminism}

Although feminist thinkers lean heavily to Foucault's theories for the articulation of their identity-politics, the irony of the fact that Foucault never subscribed to the issue of gender-construction and the politics associated with such construction remain very strong in the perception (Internet encyclopedia of philosophy). However, Foucault's conceptualization of power as an strategic function which can be fought over in different contexts has been a source of excitement for individuals and groups caught within the double-bind of colonialism and patriarchy, as an opening for staking out bold claims for identity in the relations of power. What can be noted with particular interest is that Foucault's ideas have been drawn upon by schools of feminism for interventions in different ways.

Foucault's concerns with power engage with a number of issues but do not extend as far as to include class, race or gender for that matter. The topdown model of power as an ideological imposition is too antagonistic in character to agree with Foucault's vision in which power that is exercised is also enabling: the so-called oppressed and oppressor are locked in a reciprocal bond, as authority and resistance interact upon each other simultaneously (Macclintok, 1995). This possibility of resistance within the discursive construction connected with the idea that 'the personal is political' (Heberle, 2020) has been no less than highly inspirational for the feminists whose access to the discourse enabled them to reflect critically on the narratives in which their stories have so far been framed:

To say that everything is political is to recognize the omnipresence of relations of force and their immanence to a political field; but it is to set oneself the barely sketched task of unraveling this indefinite tangled skein (Foucault, 1979b).

Within the regulatory system of the discourse, internalization of the discursive norms is a ritualistic affair-a point already discussed in the theoretical framework. In the Discipline and Punish (1979a), the important point that Foucault makes is that the spectacular nature of earlier form of punishment which involved the physical aspect of blood and death embraced a 'civilising' transformation with the passage of time, yet the spirit of pain and punishment survived in a new discursive formation where the consciousness of an individual was bound in a moral obligation to reveal its secrets to the authority. Foucault renders this point in a more telling term:

The Christian West invented this astonishing constraint, which it imposed on everyone, to say everything in order to efface everything, to formulate even the least faults in an uninterrupted, desperate, exhaustive murmuring, from which nothing must escape (Foucault, 1979c).

This murmuring is a self-exposure, an expression of guilt-consciousness that curtails one's physical freedom, while keeping one always answerable within a legal framework termed by Foucault as Panopticon (Elden, 250). Consciousness that subjects itself to surveillance is a compliant one and discourses that were in operation in the 18th and 19th century worked to scale that surveillance up by pathologizing a population that was put in a constant need of counseling from experts (Eribon, 32). Such pathologization are starkly evident in the discourses of psychoanalytic therapy where women constantly spoke of their body, their sense of the gross attached to the body and moral self-indignation induced by that sense, their petty, domestic transgression was the confessional discourse (Showalter, 1987). What is again in focus is how compliantly women reveal 
as well as shape their bodies to the demands enunciated in the form of major medical, sociological, and criminal discourses: bulimia, anorexia, depression were some symptoms that were in constant circulation in psychoanalytic discourses (Mills, 1997).

For feminists after 1960, the confessional literature was just the thing they are looking for-a site of conflict and contestation for multiple directional powers. Since discourse is never a monolithic formation, but an intriguing conjunction of asymmetric forces with procedures inbuilt to subvert authority (Weedons, 105) the confessional discourse, such as the literature by female writers of the 19th century, is always open to reworking and revision. This was clearly an opening seized by the consciousness-raising groups of 1960s, who saw in their stories a resonance of voices subversive of the frames that contained them. What is on display, beside the explicitness of weakness of the female body, is the tendency to relate this putative weakness to the structural problems of the society (BakerMiller, 1978).

By considering confessional narratives a form of discourse in which women are encouraged to 'speak out' their sins and receive there by divine favour by making themselves good and obedient to the god, female writers could transform their position of compliance into that of strength. The fact that they could record their daily impressions of life, and the tales of their miseries and deliverance was an enabling fact in itself. What was also significant, on the same note, is that such empowerment allowed women to intervene as well as engage with strategic positions such as 'truth' within a given discursive formation. This also explains the fact that access to the discourse for women, courtesy to confessional writing, marked a creative ontological space where they not only negotiated with the authority in the discourse but also made daring self-presentations, triumphantly often to outgrow the insanely-fostered stereotypes and create historical precedents for the later generations (Mills, 85). However constraints that are required to be overcome were immense and Bernstein made the critical assertion that heterosexual Victorian society at its patriarchal best took on a formidable shape not only in the confessional chamber of the Catholic priest but also in the resistance of the hostile literary critics to the innocence of Tess, the fictional heroine of Tess of the D'Urbervilles (Bernstein, 1997). Quite pertinently, therefore, the scope of resistance in the feminist discourse has been strongly argued in the writing of critics like Dorothy Smith, (1990).

There is a considerable degree of concern as to what can be done to re-work the anonymity of Foucauldian discourse to serve the individualistic purpose of women in the society-the concern in itself is quite valid, since Foucault considered subjectivity as only an effect of discursive exclusion and surveillance, not as an unified identity over time and place (Heyes, 2010). Although, authority is always contested in a discursive formation, resulting in a range of contingent power-configuration, what critics like Smith are seeking is an immediate contextbound frames of reference to that contestation, an strategic strengthening of female agency without letting it to exceed the context provided by her life and society. This is quite a modification of Foucault's theory in itself in which the bare structuralism of his thinking is wised up to the focused nature of women's struggle in society. As Smith says...

\section{Members of discourse orient to the order of the discourse in talk, writing, creating images whether in texts or on their bodies, producing and determined by the ongoing order which is their concerted accomplishment and arises in the concerting (Smith ibid).}

The question of agency has been at the centre of larger debate within the feminist discourse about how to accommodate other varieties of sexuality and how to respond to the ideological view of power. For feminists who seek to explain power within the protocols of discourse, Foucault's emphasis on the performativity of power that power is what one does rather than what one is subjected to (Youdell, 2006) has been of utmost importance in using the nonhomogeneity of female experience as the essential backdrop to explain the asymmetric behavior of female sexuality.

The ramifications of applying Foucault's ideas to a diverse range of experience in an unorthodox manner are interesting; a little concretization of the abstract nature of discourse, as it is believed, can lead us to highly enlightening assumptions of female subjectivity: 
To explore femininity as discourse means a shift away from viewing it as a normative order, reproduced through socialization, to which women are somehow subordinated. Rather femininity is addressed as a complex of actual relations vested in texts (Smith, 1990).

Femininity is thus a specific form of textually mediated relation in which the actuality of the condition precludes women to be taken for granted while mapping out a revised territory of power for their interaction and resistance on multiple sites (Walby, 1990). While Foucault had already outlined the nature of this contestation, the peculiarity of a female existence posed more problems than there were answers. Ideology was clearly an insufficient mode in depicting the place of women in the powerrelation because the patriarchal stereotypes were being outgrown by women getting access to provinces of male authority (Palmer, 1989). Problems raised by women in the problem-pages of women's magazines in the 20th century, the nagging insistence in the conduct manuals on the strict codes of morality for women of the Victorian era (Flint, 1993) were evidences to the fact that such contestation does not only exist in any given episteme as Foucault said, but more importantly, also affirms that the historical vulnerability of the weaker sex is just an example of outrageous social construction.

Having conceded that all that traditional patriarchy had done is to produce a subjected and disciplined body of the female on which the inferiority of the female is inscribed, Sandra Bartky, (1988) takes the Foucault's concepts of discourse to a radical potential:

If what we have described is a genuine disciplinea system of micro-power that is essentially nonegalitarian and asymmetrical - who then are the disciplinarians? Who is the top sergeant in the disciplinary regime of femininity? (Bartky, 76).

What Bartky is doing is to tap into the unbounded scope of the discourse of feminity, while positing that the open-endedness of discourse has the potential to exclude men, as women too, from the position of authority and privilege. The spirit of negotiation and resistance that forge new identity along an engaging curve of power-struggle can also result in dialectic of cooperation and integration, a UniversePG I www.universepg.com situation where power surprisingly accrues to individuals occupying lower niches within social hierarchy. The discourse of heterosexuality is an interesting example in this regard: while many feminists critiques heterosexuality for being the hot seat of gender-specific injustices, there is an alternative claim that individuals in a heterosexual system can stand to gain much by relating to each other's emotion and by sharing responsibilities (Mills, 1997).

Perspectives and arguments in this line evidently show that Foucauldian ideas about politics of identity and resistance are the informing agents of many critical positions within feminism, and extension to his ideas are being made at a prolific rate and frequency around the globe than can be imagined. Although it must be acknowledged that modifications made to Foucault's ideas often result in theoretical positions not entirely welcome to his original thinking, the changes and the later positions are potent evidence of the multivalency of his ideas in the changing world of theories.

\section{Foucault and Colonial/Post-colonial Studies}

While there is no doubt that the influence of Foucault in the field of colonial and post-colonial studies is undeniable, it is how his ideas are received and worked upon that lend variety to the critical positions of thinkers and researchers operating in this field. The focus is inevitably on the nature of the colonizer-colonized relationship and Orientalism as a form of knowledge linked to imperialism and colonialism. Foucault's views about the narratives of history and exclusion as a motif underpinning the formation of those narratives are vigorously taken up to reflect on issues of colonial identity and the possibility of re-inscribing a new space where identities interact in a new formation. There is, as such, no unified position among thinkers but their appropriation of Foucault's critical tools of thinking is illustrative of the fact that Foucault has remained an important point of reference in the colonial and post-colonial studies.

Said relies, for a great measure, on Foucault for the elaboration of the concept of Orientalism. Inspired by Foucault's theory of discourse, Said observes that there is an astonishing surface- regularity of the texts written about the colonized countries, that can be explained by the discursive frameworks and method- 
logies that underlie the construction of those texts. In his book Orientalism (1978), Said makes a powerful point: the idea of the Orient in a dependent cultural and political relationship with the West has to do with basic thing as making a statement. This is a key Foucauldian moment and Said has this to say:

"Everyone who writes about the Orient must locate himself vis-a-vis the Orient" (Said, 1978).

Foucault features again in Said's articulation of cultural representation. Agreeing with Foucault's view that exclusion works at the center of discursive function, Said holds that discourses of representation always tap into the possibilities of exploitation and stereotyping, enabling the west, on a purely arbitrary basis, to deify itself and demonize the east (Morris 1979). About Said's position regarding western epistemology that works collusively with imperial power-relation to produce knowledge in the spirit of devaluing and misinterpreting the orient (Richards, 1993), one can detect the unmistakable influence of Foucault with his view of disciplines working toward the reification of knowledge.

Akin to Said's position is that of Johannes Fabian (1983) who also locates the central role of the narrative in the colonial discourses. Imperialism is coextensive with the authority of the narrative, and colonizers, as he argues, employed highly nuanced strategies at the linguistic level to frame an inferior version of the orient.

Once such narrative starts-pronouns and verb forms in the third person marks another outside the dialogue. He (she or it) is not spoken to but posited (predicates) as that which contradicts with the personness of the participants of the dialogue (Fabians, 1983).

What is quite obvious is that both Said and Fabian rely on Foucault for the partial elaboration of the concept of discourse: the possibility of the agency of the colonized writing back to the center is almost non-existent. The question of agency has been picked up by Mary Louise Pratt, (1992) who has a more interesting position than both Said and Fabian on this issue. Though she agrees with Said that Western discourses, even the literary and dilettantish ones, betray a crude imperial nature (Mills, 1997), she holds that those discourses are always-already beset with gaps and fractures that exemplify both the instability of the colonizers and the resistance from the colonized. This is something she has remarkably summed up in what she termed as 'the contact zone'that social spaces where disparate cultures meet, clash and grapple with each other in a highly asymmetrical relation of domination and subordination (Pratt, 1992).

The position about agency and radical re-reading receive fuller attention from Peter Hulme, (1986) and Denis Porter (1982) who emphasizes less on Orientalist discourse as homogenizing and Universalist, as Said somewhat reductively understood, than on discourse as multilateral sites of confrontation and contestation. On this note, they are closer to exploiting full potentiality of Foucauldian discourse than Said is. Hulme locates a different construction of the orient even within the Western discourses. To believe that orient was always portrayed as inferior without exception is not to consider Orientalism as a discourse at all. Depending on who writes about which part of the world has given rise to different narratives of the East (Macclintok, 1995). There is no one orient; similarly, the relationship between the west and east cannot be placed under one unified category. In any sense, "no smooth history emerges, but rather a series of fragments, which read speculatively, hint at a story that can never be fully recovered' (Hulme, 1986). And Porter holds Said quite un-postmodern too: the latter's conviction that the Orientalist discourses are oppressive without exception is to confer on signs of representation a rare quality of stability. This means that colonial experience is an unbroken continuity, being 'not only what we have but all we can ever have' (Porter, 1982). Both Hulme and Porter, aware of Foucault's view that discourse always charts out new passage to the formation of identity, mark a decisive departure from Said. Very eager to blame West for everything bad that happened due to Orientalism, Said indulges himself in another form of idealism that not only opens Said to the charge of promoting Occidentalism, it also contributes to the perpetuation of that Orientalist thought he set out to demystify in the first place (Porter, 1982).

The contribution of Foucault in the advancement of colonial and post-colonial studies is immense. The typical Foucauldian insight that disciplinary surveillance and regimentation not only rupture 
authority but also provide incitement to multiple identities encouraged post-colonial thinkers to explore history as a series of narratives with no defined hierarchy. This point has been enthusiastically elaborated by Gayatri Spivak and other thinkers of Subaltern Studies Group. They have also discarded the conventional view of the orient, which is again a theoretical move away from Saidian brand of Orientalism. In her study of the social history of Indian subcontinent, Spivak found that the society had many layers of classes, with each class having their unique history of domination and submission. The dynamic of relationship between the upper class Hindu and Hindu of the lower class is no less oppressive than that between the colonizer and the colonized in general; in fact the lower class Hindus, in the cast-ridden society of India, were the locus on which colonialism at its most aggressiveness, was concentrated-a fact otherwise ignored when the colonizer-colonized relationship is generalized. Her point is that elite Brahmins, the upper-caste Hindus can 'be shown to have the same intentions as (thus providing legitimation for) the codifying British' (Spivak, 1993). Spivak's attention therefore falls on recovering the voices of the non-elite colonized erased by the nexus of the colonizer and the elite colonized, and the idea that colonized other is 'irretrievably heterogeneous' (Spivak, 1993).

The colonial other is also a very problematic idea for Homi K Bhaba. For him, the experience of colonial encounter is one of deep transformation, brings about changes along psychological and political lines and turns the relations of power into something highly ambivalent. The Lacanian bent in his thinking gave him a different angle of looking at the formation of subjectivity, with the possibility of modifying colonial discourses in the psychological direction (Low, 1996). The 'other' is not the lack of the colonising 'self' but a psychological dialectic that holds in the colonial norms and the desire to transcend those norms, resulting in a state of the colonized that Bhabha identifies as mimicry:

Colonial mimicry is the desire for a reformed recognizable other, as a subject of a difference that is almost the same, but not quite. Which is to say, that the discourse of mimicry is constructed around ambivalence . . Mimicry is thus . . the sign of the inappropriate, however, a difference or recalcitrance which coheres the dominant strategic function of colonial power, intensifies surveillance, and poses an imminent threat to both normalized knowledge's and disciplinary powers (Bhabha, 1994).

The long quote serves to highlight the fact that the colonized are not located at the receiving end of power but designate a strategic function where resistance is proportionate to the possibility of surveillance and disciplinary power. Ostensibly, Bhabha's position on the colonial experience aligns him well with Foucault's view that conflict of interest and power is fundamental in the multiple and varied formation of identities. In that sense, Bhabha's understanding of colonial experience as the volatilization of the status quo in respect to the hierarchy of power is a tactical shift away from the theoretical angles that look at the Orientalist discourses as unilaterally oppressive. It is evident that Foucault's ideas have been adapted by different theorists in different ways in their colonial and postcolonial capacities. The diversity of their approach to and undertaking of Foucault's theories betoken their relevance in the realm of critical thinking. The difference of the followers of Foucault is a reflection of the conflicting strands within his ideas. Said's applications of discourse to explain colonial experience as overwhelmingly oppressive is indifferent to the role of human agency in history. This problem is not Said's alone but Foucault's too. His commitment to believe that consciousness comes to know itself within discourse is responsible for the anonymity of the discursive procedures and the generality that accrues to it (Khaghani, 2019).

Again, Foucault's locating resistance as coeval with enforcement of power has been very compelling toothis allowed many post-colonial thinkers to have anti-reifying strategies against reifying rituals of power. While the debate between Saidians and antiSaidians is still going on about the nature of orientalist knowledge in the colonial and the postcolonial world, Foucault's theoretical creeds have been the powerful underpinning of those debates.

\section{CONCLUSION:}

Michael Foucault was one of the biggest thinkers of the last century and his constellations of ideas continue to have rich legacy among thinkers of various critical schools. Those are ideas that have had a phenomenal reaction and response during his 
days and afterwards. It can be safely assumed that his anti-humanistic approach to history, rejection of ideological construction of power, theorization of power as an open-ended participatory situation were those unprecedented and challenging intellectual positions that the global, not to say the western, intelligentsia had confronted for the first time. As much as there was a severe reactionary stand from certain quarters to his position(since he ruffled some authoritarian feathers), others that were socially deprived, politically disadvantaged and sexuality marginalized, saw in his intellectual intervention a liberating scope. Of all the thinkers who had critical backgrounds, those who worked within feminist and colonial discourses, made theoretical moves to adapt Foucault's views about identity and knowledge/ power nexus to consolidate their position based on resilience and resistance toward institutional authorities. While adaptation of Foucault's ideas to diverse activist positions became a cultural trend, it became evident that there was really no unanimous position among thinkers who wanted to make the most out of Foucault. The point of dilemma for the thinkers was that while Foucault spoke of power and resistance as twin sites of a single node, he always stopped short of espousing power for any discreet political purpose or for narratives with ideological bias. The post-Foucauldian critical milieu was characterized by attempts to overcome the dilemma by bringing modifications to his ideas, where necessary, and by giving a cadence of political involvement to the more generalized parts of his ideas. While such modifications may not be in line with Foucault's original intentions, such practices are stimulants of radical positions excited by consciousness of identity and commitment. This paper is an attempt to bring into focus some of the remarkable theoretical endeavors to engage with Foucault's ideas from diverse locations and the process by which those engagements are made.

\section{ACKNOWLEDGEMENT:}

The authors would like to thank the faculties of the Dept. of English, University of Barishal, Barishal, Bangladesh for their valuable suggestions in writing this article.

\section{CONFLICTS OF INTEREST:}

The authors declare no conflict of interest with respect to the research.

\section{REFERENCES:}

1) Akter MS, Hossain MA, Akter F, Shirin S, and Zalil MA. (2019). A Feministic approach to Nora of Henric Ibsen's A Doll's House, Br. J. Arts Humanit., 1(5), 28-34. https://doi.org/10.34104/bjah.019.28034

2) Bristow Joseph, (2001). Sexuality. The New Critical Idiom, Routledge: London and New York.

https://www.routledge.com/Sexuality/Bristow/ p/book/9780415299299

3) Baker-Miller, Jean. (1978). Towards a New Psychology of Women, Penguin, Harmondsworth.

4) Bartky, Sandra. (1988). 'Foucault, femininity and the modernization of patriarchal power', in Diamond, Irene and Quinby, Lee (eds) Foucault and Feminism: Reflections of Resistance, North Eastern University Press, Boston: 61-117.

5) Bhabha, Homi. (1994b). 'Of mimicry and man: the ambivalence of colonial discourse', in Bhabha, The Location of Culture, Routledge, London: 85-93.

https://www.jstor.org/stable/778467? origin=JS TOR-pdf

6) Bernstein. Susan David. (1997). Confessional Subjects: Revelations of Gender and Power in Victorian Literature and Culture, The University of North Carolina Press: Chapel Hill and London.

7) Davis, Lennard. (1983). Factual Fictions: The Origins of the English Novel, Columbia University Press, New York. https://www.jstor.org/stable/437677?seq=1

8) Elden Stuart and Crampton Jeremy W. (2007). Space, Knowledge and Power: Foucault and Geography, Routledge: London.

9) Eribon, Didier. (2001) "Michel Foucault's Histories of Sexuality", Journal of Lesbian and Gay Studies, 7(1): 31-86.

https://doi.org/10.1215/10642684-7-1-31

10) Foucault, Michel, (1972). The Archaeology of Knowledge, trans. Sheridan Smith, A. M., Tavistock, London (first published 1969).

11) Foucault, Michel, (1977a). Language, Counter-memory, Practice: Selected Essays and Interviews, ed. Bouchard, D. F. and 
trans. Bouchard D. F. and Sherry, S., Blackwell, Oxford. https://pages.mtu.edu/ rlstrick/rsvtxt/foucault1

12) Foucault, Michel, (1978). The History of Sexuality, Volume 1: An Introduction, trans. Robert Hurley (New York: Random House).

13) Foucault, Michel, (1979a). Discipline and Punish: The Birth of the Prison, Vintage/ Random House, New York. https://en.wikipedia.org/wiki/Discipline and Punish

14) Foucault, Michel, (1979b). 'Interview with LucetteFinas', in Morris, Meaghan and Patton, Paul (eds) Michel Foucault: Power/Truth/Strategy, Feral Publications, Sydney: 67-75.

15) Foucault, Michel, (1979c). 'The life of infamous men', in Morris, Meaghan and Patton, Paul (eds) Michel Foucault: Power/Truth/Strategy, Feral Publications, Sydney: 76-91.

http://storage.ugal.com/3871/lives-ofinfamous-men.pdf

16) Foucault, Michel, (1979d). 'Powers and strategies: interview between Michel Foucault and Revoltes Logiques collective', in Morris, Meaghan and Patton, Paul (eds) Michel Foucault: Power/Truth/Strategy, Feral Publications, Sydney: 48-58.

17) Foucault, Michel, (1979e). 'Truth and power: an interview with Alessandro Fontano and Pasquale Pasquino', in Morris, Meaghan and Patton, Paul (eds) Michel Foucault: Power/Truth/Strategy, Feral Publications, Sydney: 29-48. https://doi.org/10.1177/0308275X7900401311

18) Foucault, Michel, (1981). 'The order of discourse', in Young, Robert (ed.) Untying the Text: A Poststructuralist Reader, RKP, London.

19) Frow, John. (1985). 'Discourse and power', in Economy and Society, 14(2), 192-214. https://doi.org/10.1080/03085148500000010

20) Flint, Kate. (1993). The Woman Reader 1837-1914, Clarendon Press, Oxford.

21) Fabian, Johannes. (1983). Time and the Other: How Anthropology Makes its Object, Columbia University Press, New York. http://cup.columbia.edu/book/time-and-theother/9780231169264
22) Hamilton Paul. (2004). Historicism. $2^{\text {nd }}$ Edition the New Critical Idiom, Routledge: London and New York.

23) Hulme, Peter. (1986). Colonial Encounters: Europe and the Native Caribbean 14921797, Methuen, London.

http://repository.essex.ac.uk/9277/1/Hulme\%2 C\%20Colonial\%20Encounters.pdf

24) Heyes, C. (2010). "Subjectivity and Power". In D. Taylor (Ed.), Michel Foucault: Key Concepts, pp. 159-172.

25) Heberle Renée The Personal Is Political, First published: 22 April 2020, Retrieved from -

https://doi.org/10.1002/9781405165518.wbeos p018.pub3

26) KhaghaniSaeid.(2019). "Foucault and the idea of "architectonic discourse" or how to read others' history", Cogent Arts \& Humanities, 6(1), Retrieved from https://doi.org/10.1080/23311983.2019.16015 $\underline{41}$

27) Mills Sara. (1997). Discourse, Routledge: London.

28) McClintock, Anne. (1995). Imperial Leather: Race, Gender and Sexuality in the Imperial Contest, Routledge, and London.

29) Macdonnell, Diane. (1986) Theories of Discourse, Blackwell, Oxford. https://www.jstor.org/stable/1773010?seq=1

30) Morris, Meaghan. (1979). 'The pirate's fiancée', in Morris, Meaghan and Patton, Paul (eds) Michel Foucault: Power/Truth/ Strategy, Feral Publications, Sydney: 148168.

31) Pratt, Mary Louise. (1985). "Scratches on the face of the country: or what Mr. Barrows saw in the land of the Bushmen", Critical Inquiry, 12(1), 119-143.

32) Porter, Dennis. (1982). "Orientalism and its problems", in Barker, F. (ed.) The Politics of Theory, Proceedings of the Essex Sociology of Literature Conference, University of Essex, Colchester.

33) Palmer, Paulina. (1989). Contemporary Women's Fiction, Harvester, Hemel Hempstead.

34) Richards, Thomas. (1993). The Imperial Archive: Knowledge and the Fantasy of Empire, Verso, London. https://www.jstor.org/stable/27794759?seq=1 
35) Spivak, Gayatri Chakravorty. (1993). "Can the subaltern speak?" in Williams, Patrick and Chrisman, Laura (eds) Colonial Discourse and Post-colonial Theory, Harvester Wheatsheaf, Hemel Hempstead: 66-111.

https://www.nottingham.ac.uk/english/docume nts/innervate/09-10/0910rosssubaltern.pdf

36) Smith, Dorothy. (1990). Texts, Facts and Femininity: Exploring the Relations of Ruling, Routledge, London.

37) Showalter, Elaine. (1987). The Female Malady: Women, Madness and English Culture, Virago, London. https://doi.org/10.1177/003803859402800101 $\underline{6}$

38) Said, Edward. (1978) Orientalism, Routledge \& Kegan Paul, London.
39) Walby, Sylvia. (1990). Theorizing Patriarchy, Blackwell, Oxford.

https://journals.sagepub.com/doi/10.1177/0038 038589023002004

40) Weedon Chris. (1987). Feminist Practice and Poststructuralist Theory, Blackwell Publishing, Oxford.

41) Youdell Deborah. (2006). "Subjectivation and Performative Politics: Butler Thinking Althusser and Foucault: Intelligibility, Agency and the Raced-Nationed Religioned Subjects of Education." British Journal of Sociology of Education, 27(4), pp. 511-528. JSTOR, Retrieved From www.jstor.org/stable/30036159. Accessed 1 $\underline{\text { Jan. } 2021}$

Citation: Faysal YA., and Rahman MM. (2021). Impact of foucauldian discourse on Feminism and postcolonial studies, Br. J. Arts Humanit., 3(1), 1-10. https://doi.org/10.34104/bjah.021010010 (9) 